Journal of Social Sciences (COES\&RJ-JSS)

ISSN (E): 2305-9249 ISSN (P): 2305-9494

Publisher: Centre of Excellence for Scientific \& Research Journalism, COES\&RJ LLC

Online Publication Date: $1^{\text {st }}$ October 2015

Online Issue: Volume 4, Number 4, October 2015

http://www.centreofexcellence.net/J/JSS/JSS Mainpage.htm

\title{
A COMPARATIVE STUDY ON SELF-ESTEEM OF WORKING AND NON-WORKING WOMEN IN PAKISTAN
}

\begin{abstract}
Fareda $\mathrm{Zeab}^{1}$ and Uzma $\mathrm{Ali}^{2}$
Abstract:

The purpose of this study was to explore the difference of self-esteem between working and non-working women of Pakistan. It was hypothesized that 'the working-women will score higher on the variable of Self-esteem as compare to non-working women. The sample of 250 (125 working, 125 non working) women were taken by purposive sampling technique. The target group's age range was between 28 years to 45 years. The Mean score of age was $(M=34.126)$ and the standard deviation was $(S D=4.129)$. The women were selected from different organizations and areas of Karachi, Pakistan through purposive sampling technique. After taking the permission from authorities and informed consent from the participant demographic forms were filled then in order to measure the self-esteem, Rosenberg self-esteem Scale (RSES, 1965) was administered, individually. Descriptive statistics and t-test for independent mean were used to analyze the data through SPSS. It was concluded that non-working women are likely to have higher selfesteem than working-women in Pakistan.
\end{abstract}

Key words:

Self-esteem; working women; mental health.

Citation:

Zeab, Fareda; Ali, Uzma (2015); A comparative study on self-esteem of working and nonworking women in Pakistan; Journal of Social Sciences (COES\&RJ-JSS), Vol.4, No.4, pp: 934-944.

http://dx.doi.org/10.17632/d564n78n3m.1

\footnotetext{
${ }^{1} \mathrm{PhD}$ fellow, department of psychology, University of Karachi Email: faredazeab@yahoo.com

${ }^{2}$ Associate Professor, Institute of Clinical psychology, University of Karachi

(C) Author(s) 2015. Licensed under the Creative Commons License - Attribution 4.0
} 


\section{INTRODUCTION}

Rosenberg (1965) defines self esteem as "The totality of the individual's thoughts and feelings having reference to him/her self as an object".

Rosenberg (1965) termed the self-esteem as a distinct phenomenon called 'self' having societal responses, either positive or negative. Self-esteem is a reciprocal psychological interaction; between the social indicators (for example culture and norms) and the person's type of personality for example introvert Vs open or sober Vs talkative.

Rosenberg also explained that self-esteem is a compound response of one's perception or self worth and one's image in others mind. A person reflects the people thinking towards $\mathrm{him} / \mathrm{her}$, every human with normal or high self-esteem takes him/her self wanted and valuable. In contrast, a person with low self-esteem feels rejected, incapable and worthless.

Zehra (2002) observed that multiple roles provide working women cognitive cushioning, high self-esteem and gratification, particularly when life happenings are not in one's control. Multiple roles in life such as wife, mother, sister, employee lead to a lower level of depression and a higher level of self-esteem than those who are not married, employed or have children (Alavi, 2013; Bandura, 2006).

Rogers (1947) explained that one's self worth grows gradually with social net working and relations. Self-esteem develops when a person receives "unconditional positive regard". The conditional positive regard affects the self-esteem making it dependent on others expectations rather than its natural capability. One unduly attempts to please others to gratify its own needs of appreciation and belongingness.

Abraham (2011) mentioned that girls are lesser valued than boys in Pakistan. People conditionally regard the daughters, the sisters and the wives, so that women likely have affected self-esteem. Although, Alavi (2013) agreed with the earlier mentioned some studies reported that employed women possess more sound psychological and mental health status than housewives. Number of large scale studies concluded that those women who are working and considered that their professional role is a source of self-fulfillment scored higher on satisfaction level on life scale. In another study Alavi and Askaripur, (2013) supported that possessing multiple roles is considered as an enhancement of women's well-being such as; chances to learn, build social networking, to develop selfefficacy and self-esteem, open access to informational, emotional and instrumental support and to safeguard their life from different stressful situations. On the other side some studies including Zeab (2011) argued that employed women stand on a lower level of psychological well being. Though there are some studies (Cash, 2002) found that no difference between working and non-working women in the status of psychological well being. Whether or not employment status is worthy and beneficial to women's well-being is still not a firm conclusion. It also depends on some other variables such as working conditions, organization type, subjective perception of a person, and satisfaction with the job (Ali, Khan and Munaf, 2013).

Gunnestad, (2006) revealed that in the most areas of Pakistan's society, people live in joint family system compelling strictly follow the norms. The joint family system in Pakistan and India strongly influence the habitants. There are two out of ten families who avoid sending their female children to schools due to the adherence of old conservative customs and traditions (Farida and Mumtaz, 2010). Since they perceive that why a woman should get education as education is only necessary for work purpose and there is no use of it in 
their daily lives. The non working-women are having lesser liberty, facility of mobility and access to civilized quality of life as they are compelled to live within the four walls (Zehra, 2002). In a recent study of Women's mental health found that over 13 million Pakistani populations, the proportion of female is $52 \%$.The literacy rate of females in Pakistan is significantly low i.e. about $1.8 \%$. It is due to lack of attention by the successive Governments. A very low percentage of total Gross Domestic Product (GDP) is allocated for education in Pakistan, which is alarming. Furthermore, access to education for females is another major issue in Pakistan.

However, education in urban areas is bit easier as compared to rural areas of Pakistan. In the rural areas schools are far away from home and have no proper transport facility and those, which are there, have fewer resources to educate their children.

Although, currently working-women are not as much bounded as they were in the past and they are enjoying most of their liberties and rights as provided by constitution of Pakistan and International Charter of Fundamental Human Rights. Especially in developed areas of Pakistan e.g. Karachi and Islamabad, girls are getting educational privileges equally in the schools, colleges and universities side by side with boys. Mostfa, (2005); Farida and Mumtaz, (2010) stated in their discussion that currently, the boundaries between working and non working-women are being broken by rising awareness through media. Globalization is exerting a positive change in the life of women living in the villages and cities. However, it is also observed that females are still the target of victimization at various places in urban areas as well. It was also found out that those females, who work and living in the cities still facing difficulties to get admission in schools, institutes and getting jobs.

On the other hand, People permanently living in urban areas respect and value their women to be a part of earning member of family and their status is comparatively improved in comparison to the past. Mostafa (2005) argued that such positive attitude towards working women shelter them from feeling of rejection and being failure or mental illness. They feel confident and honorable.

Unlike, the Western society, Ossai, (2011) highlighted that Pakistan's society has a male dominant culture, where a male is responsible for financial and domestic matters. Males are perceived as the responsible and powerful person. It is further observed that people in Pakistan and India feel emotionally upset, on the birth of a daughter whereas, on the birth of a son is taken as a source of celebration.

It was also observed that initially, people avoid to get marry with a girl who is working but now they look for a working spouse as she could serve as a supporting hand and nurture her children in a better way than a traditional housewife. Now, people acknowledge the working women's contribution to combat the financial needs of their families that is assumed as the guarantee of prosperous future of their families.

The case in the conventional era in which women were supposed to stay at home and men had to earn the livelihood for their family that is still working out in many rural areas of Pakistan.

These variations seem to have a stronger impact on lower middle class families than working and upper class families. Esomonu, (2010); Shireen, and Zeba, (2011) defined the difference of socio economic status and the level of disadvantages in the housewives' status. It was spelled that females who belong to upper and middle socioeconomic strata of Pakistan are keen to social, political and economic benefits. Meanwhile, some females from the upper and lower classes also enjoy social, political and economic status. Zeab 
(2011) mentioned that most of the females who belong to the elite families have different types of apprehensions, such as they have no burden of households responsibilities due to servants and have no need to do a job for financial gains, rather they have worries regarding dependency on their husbands and they feel insecure of being neglected by the husband due to a second woman. When a female is not doing a paid job or contributing financially, she is at the stake of her husband that how he treats her, as she fully dependents on him. Shireen, and Zeba, (2011) observed that the dominant males over the dependent females feel themselves as well-fed, well-dressed and well ornamented slaves of their husband who use them for full filling their urges. Their husbands treat them in inhuman ways but they have no other option except living with them.

In a study on Social Status of Rural and Urban Working Women in Pakistan, Fatima (2007) found that in the last decade, the professional literature has addressed employed and household women on a continuum. A working- woman, generally, has a higher level of formal education, a higher level of income, and more social relations than the counterpart. A working-woman also typically lives in a resource-rich environment and has greater access to prenatal care and public transportation. The reduced geographical distance between family and friends in the working-women results in less social isolation as compared to the non working-women. These characteristics may have a negative impact on the non working-women who may be less able to read and understand patient education materials, afford or access routine healthcare and attend regular appointments. These factors may negatively influence the woman's attempt to deal with unfamiliar symptoms and life challenges. Different studies including Hanam and Lee (2006) added that residents of non working-women often have lower educational levels, lower socioeconomic levels, more insecurity, and have greater travel distances to access healthcare than their (working-women) counterparts.

Alavi (2010) studied on Gender difference that in Asian society for example India, Pakistan, Srilanka and Malaysia the most of the dominating positions are in males' hands and females are just passive part of the society and mostly females married through an arranged marriage system within the families and they have no choice to give their inputs to their parents or family's (Biraderis) decision. No female particularly in rural area can run her business without the "saya" (shelter) of a male. Moreover, in the poorer areas daughters are sold for monetary purposes to their future husbands who sell them after divorce. A female who accepts this is given as a prized object. This practice is also happening in Indian Occupied Kashmir and the beautiful girls are sold to brother houses (Alavi, 2010).

The literature indicates the significance issues on the mental well being of female. Keeping in mind, it is felt that the relation to the problem of the self-esteem among working and non-working females of Pakistan is an important issue, needs to be investigated.

Since, there is very limited evidence across the country on the current theme, the report will be considered as a comparative mode on self-esteem among working and nonworking women. All the research cited in the literature review indicates that a Western evaluation on current issue addressed and it is hard to replicate for the working and nonworking segment of Pakistan. Research in this area in Pakistan is negligible and hardly provides any basis for valid assertion about the state of affairs and the remedies. If ever adapted by authority, to improve the Psychological and mental well-being of the targeted population, this study will help out the ways well-being of the target group.

The aim of the study is to evaluate the difference of Self esteem among working and nonworking women, living in Karachi, Pakistan. Early studies suggested that working women 
are likely susceptible to being sexually discriminated and harassed at the work place. They might feel more insecure and they are likely to be mentally instable compared to non working females.

The present paper will focus on researches done all over the world and previous researches conducted in Pakistan with reference to the effect of work place environment, mental health status of women and contributing factors for psychological issues faced by women.

The objectives of the present study are to examine the differences between mental health status of working and non working women in Pakistan. For this purpose the author selected the variable of self-esteem, since this factor is very important for working women all over the world and in Pakistan as well. This study will further evaluate that whether, those women who utilized their knowledge and skills at work place suffer more often from low self esteem or their work has a positive effect on their mental health? Previous researches mentioned above, showed that working women have lesser psychological problem as compared to those who are at home and don't have any outlet to utilize their inner potentials and resources. Further the findings of this study would be helpful for psychologists to understand the phenomenon in better way, and thereby to help women in different discipline.

The present study will evaluate the significance of the factors those cause low self-esteem among working or non-working females. Such as working environment, safety hazards at work place, job/financial insecurity, gender discrimination and lack of gratification of the needs. The results of the study will be helpful to review the norms of the society, which are contaminating the society. The myths could be addressed and replaced by the modern realities; which are globally under practiced.

Research on mental health may consider as a strategic opportunity for Pakistan as it can lead to the realization of quality of life for the working-women.

The diagnosis and awareness by the research may gain the economic benefits for the country as a whole. According to WHO's report (2006) that good self-esteem impact will only be minimized if aggressive interventions are created and widely spread.

Unfortunately, there is a lacking of researchers in Pakistan with expertise in the workingwomen mental health services research. Particularly, the working-women's mental health promotion, information about the health and the working environment is needed to be synergized.

The paper also considered that, there has been a shortage of corporation among mental health disciplines in the planning and carrying out of research initiatives. The study paid attention to the life sciences, including women-mental health research. It will hold a prime promise for maximizing women's overall health and minimizing the social and economic effects of the ailments.

In spite having the potential and talent in the working females, there is insufficient mental health research efforts, currently, exist in Pakistan. This paper for mental health research recognizes that there is still much more work to do in building the research capacity in the area of mental health, especially in the segment of employed women's mental health. The 
researches on this subject on the targeted population will enhance the relevancy of research; and to ensure it is used to support practice and policy.

Since, previous researchers found that working women seem to be confident because of dealing more stressors at the work place and home. They might have better self-esteem and lesser chances of mental instability compared to non working females, who stay at the homes. Considering the past researches, it was hypothesized that:

The working-women will score higher on the variable of Self-esteem as compare to nonworking women.

\section{METHOD}

Participants

The sample for the current study was taken from Karachi city. Since, Karachi is considered as a capital of province named Sindh. Karachi is a multi populated city of Pakistan and the people who belong from different areas around Pakistani come to earn a living for their families here. Since, ample and multi cultured people live in the city the data of this city may has a significant value to generalize as Pakistan's sample. An easily available of targeted women such as teaching, non-teaching staff, women Bankers, paramedical staff and house wives were chosen from various commercial organizations including, Jhangeer Siddiqui Bank Ltd, Cresguard Systems (Pvt) Ltd, Fulcrum pvt Ltd as well as Jinnah Hospital. A total sample of 250 women was taken for the study. It was further broken in to two groups of 125 non-working women and 125 working-women. The age range was between 28 to 45 years $(\mathrm{M}=34.12 ; \mathrm{SD}=4.12)$ for entire sample. The sample's minimum level of education was 14 years.

\section{Measures}

\section{Demographic Sheet}

In order to explain the implications of the study, researchers must gather the personal information of the participant such as marital status, education, age, income, occupation and family structure etc. To collect the demographic information of the women, a demographic form was written and given to the women.

\section{b) Rosenberg Self-Esteem Scale (RSES) (1965) (Appendix F)}

The scale is widely used to measure the self-esteem. The scale consists of total 10 items with 4-point Likert-type scale; 1 is strongly disagree, 2 is disagree, 3 is agree, 4 is strongly agree. $50 \%$ of the items are reversely scored that indicates that lower the scores, higher the self-esteem. Greater than 20 scores depict the positive self-esteem. Normally, participants take 5-10 minutes to complete the questionnaire. The scale has high Reliability and Validity.

"The internal consistency range from $0.75-0.92$ and test-retest reliability is $0.85-0.88$ concurrent validity of Rosenberg self-esteem scale is 0.60-0.72' ' (Rosenberg, M. (1965).

\section{Procedure}

In order to collect the data of working women, first of all, multiple commercial organizations were approached. The organizational heads were explained the purpose of the research and a "Request of permission to collect the data, was also be asked. The telephonic and e-mail permissions were taken. The letters of consent were given to the non-working females in physical presence. Secondly, in the view of obtained official 
permission, the samples were approached comfortably and then individually briefed the reason of the research. They were told the ethics of research participation as a volunteer subject. The women were informed that they could withdraw their participation at any time. The confidentiality of the findings was also being rest assured. Thirdly, they were requested to sign the consent form to participate in the research. A demographic form containing personal questions such as age, marital status, education, socioeconomic status, income, family structure, occupation, profession was asked to fill. Each participant was interviewed separately (one participant at a time). All of the participant's marital status was constant; married. Finally, Rosenberg Self-esteem Scale (1965) was administered to the participant women to gauge their self-esteem.

The women, who were taken as a control group in the study, were approached at their homes and universities (students). They had no background history of paid work. The same procedure was applied to gather the information from non-working women, just as for working women.

\section{RESULTS}

Statistical Package of Social Sciences (SPSS; V 16) was brought forward to analyze the information. 0.05 was the significant level for entire analysis. In order to evaluate the level of differences among the variables, $t$-test was applied. To interpret the results Descriptive statistics was opted.

The t-test indicates that working-women showed higher mean scores on the variable of self-esteem than the mean scores of non-working women.

\begin{tabular}{|c|c|c|c|c|c|c|}
\hline \multirow[t]{2}{*}{ Age } & \multicolumn{2}{|c|}{$\begin{array}{l}\text { None-Worktng- } \\
\text { Women }\end{array}$} & \multicolumn{2}{|c|}{ Working-Women } & \multicolumn{2}{|c|}{ Total } \\
\hline & $F$ & $\%$ & $F$ & $\%$ & $F$ & $\%$ \\
\hline 28 & 5 & 4 & 5 & 4 & 10 & 4 \\
\hline 29 & 4 & 3 & 4 & 3 & 8 & 3 \\
\hline 30 & 16 & 13 & 16 & 13 & 32 & 13 \\
\hline 31 & 14 & 12 & 14 & 12 & 28 & 12 \\
\hline 32 & 6 & 5 & 6 & 5 & 12 & 5 \\
\hline 33 & 10 & 8 & 9 & 8 & 19 & 8 \\
\hline 34 & 13 & 10 & 13 & 10 & 26 & 10 \\
\hline 35 & 13 & 10 & 14 & 10 & 27 & 10 \\
\hline 36 & 9 & 7 & 9 & 7 & 18 & 7 \\
\hline 37 & 8 & 6 & 8 & 6 & 16 & 6 \\
\hline 38 & 2 & 2 & 2 & 2 & 4 & 2 \\
\hline 39 & 11 & 9 & 11 & 9 & 22 & 9 \\
\hline 40 & 5 & 4 & 5 & 4 & 10 & 4 \\
\hline 43 & 4 & 3 & 4 & 3 & 8 & 3 \\
\hline 44 & 4 & 3 & 4 & 3 & 8 & 3 \\
\hline 45 & 1 & 1 & 1 & 1 & 2 & 1 \\
\hline Total & 125 & $100.00 \%$ & 125 & $100.00 \%$ & 250 & $100.00 \%$ \\
\hline
\end{tabular}


Table 2

Table 2 presents the $M$ and SD of the entire sample.

\begin{tabular}{|c|c|c|c|}
\hline Age & $\begin{array}{l}\text { Non-Working- } \\
\text { Women }\end{array}$ & $\begin{array}{l}\text { Working- } \\
\text { Women }\end{array}$ & Total \\
\hline $\mathrm{N}$ & 125 & 125 & 250 \\
\hline Meas & 34.46 & 34,47 & 34.126 \\
\hline Std. Deviation & 4.138 & 4.136 & 4.129 \\
\hline
\end{tabular}

Table 3

Mean Scores of working and Non-Working women on the variable of Self Esteem.

\begin{tabular}{lcccccc}
\hline Variable & N & M & SD & SEM & T & Sig \\
\hline Self esteem & & & & & & \\
Non-Working & 125 & 16.41 & 6.51 & 0.53 & & $0.029^{*}$ \\
Working & 125 & 18.01 & 4.86 & 0.43 & & \\
\hline
\end{tabular}

Note: $d f(248) ; p<.0 .05^{*}$

The table no. 3 shows the mean value of working-women is greater than mean value of non-working-women, and standard deviation shows the precision in working women that is why working women standard error of mean is low. P-value being less than level of significant shows that there are statistically significant differences in the mean scores of working and non-working women on the variable of self esteem.

The p-value is maximum probability accoutering in true probability-value is less than level of significance its mean significant relation between the variables.

\section{DISCUSSION}

The results revealed that the employed females possess higher Self-esteem than the house wives. The hypothesis is being met that the working-women will score higher on the variable of self-esteem as compare to the non-working-women. The working-women scored higher than the non-working-women on the variable of self-esteem. Concentrating on working-women, if picks up the relevant material from Farida and Mumtaz (2010) that employed females feel themselves as competent and ready to face the challenges in modern day society being more cultured and confident due to their financial and professional position. The scores reflect better psychological health of the workingwomen, Alfred Adler's (1964; 1971) theory of inferiority complex, support the phenomena that a woman, having innate sense of inferiority, utilizes the potential motivational energy to overcome the inferiority feelings. She strives to rise, to gain respect and fame. Since, working-women got higher scores than non-working women on the variable of self-esteem, it may be considered as a good sign leading to the theory that working-women are well aware of the psychological needs and manage them well. They, for this reason, have stronger inferiority feelings, furthermore, they have stronger desire to be respected and to be loved (Maslow, 1954). These needs, perhaps, substantially motivate the women to work and gratify the inner feelings rather than the physical comfort. 


\section{CONCLUSION}

According to the result's higher self-esteem figures, the employed women are felt to be confident, organized and practical. Employed women's better mental health condition than none employed one, points out the urge to providing the emotional security to the working women. The lowered scores on the variable of self-esteem of house wives showed the instable mental health than working women.

\section{RECOMENDATIONS}

These findings need to be re-researched with the new dimensions, in future. The sample group should include some major cities across Pakistan for example Peshawar, Lahore, Hyderabad and Quetta. It will give expansion to the study and also various professions for instance blue collar jobs such as house maids, female labor; factory workers may also be included in the future studies. Future studies should strongly requisite consideration of the relationship of the important demographic variables with self-esteem among women.

The study is a road map for the researchers and scholars of Pakistan with few limitations. This study may be implemented by concern authorities especially, in organizations for policy making. Lastly, this study may be very beneficial for not only having a healthy organizational culture but also for societies and household issues.

As a result of paying attention to the issues which are ruled out in the current research, a moderate society may be promoted. The extremist practices could be turned down and the basic human rights be enjoyed.

\section{AKNOWLEGEMENT}

I am grateful to Dr Uzma Ali, Associate Professor, Institute of Clinical psychology, University of Karachi, helping me to write the article. I am also thankful to the participants and authorities of different organization in Karachi Pakistan for their cooperation in data collection.

\section{REFERENCES}

Abraham, A. (2011). Isolation as a form of marital violence: Journal of Social Distress and the Homeless, 20 (22) 221-226.

Alavi, H., \& Askaripur, M. (2013). The relationship between self-esteem and job satisfaction of personnel in government organizations. Public Personnel Management, 32 (4), 591-598. [Accessed 3 September 2013]

Retrievedfromhttp://www.ourworld.compuserve.com/homepages/sangat/pakwomen.htm

Alavi, H. (2010). "Pakistani women in a changing society”. [Accessed 24 August 2013] Retrieved from: http://ourworld.compuserve.com/homepages/sangat/pakwomen.htm Ali, U., Khan, A., \& Munaf, S. (2013) Attitudes toward Women in Managerial Position in Pakistan: International Journal of Information and Education Technology, 3 (3), 373-377.

Bandura, A. (1991a). Self-efficacy mechanism in physiological activation and healthpromoting behavior. Neurobiology of learning, emotion and affect, 4, 229- 270. New York. 
Bandura, A. (1991b). Self-regulation of motivation through anticipatory and selfregulatory mechanisms: Perspectives on motivation: Nebraska symposium on motivation, 38, 69-164, Lincoln: University of Nebraska Press.

Bandura, A. (2006). Social foundations of thought and action: A social cognitive theory, Englewood Cliffs, NJ: Prentice-Hall.

Cash, F., \& Gild, P. (2002). Body Cathexis and the Self. Journal of Consulting Psychology, 17 (4), 347-349.

Cash, F. (2004). Body image: Past, present, and future. In B. C. Bressman (2004). Weight related teasing: Relationship to body image, self-esteem and relative body size of adult females. Unpublished Ph.D. dissertation, Graduate School of the Ohio State University.

Esomonu, J.C. (2010). The relationship of employment to self-perception and well-being in women: A cognitive analysis. Journal of Teacher Education and Teaching, 8 (1), 360366.

Farida, S., \& Mumtaz, K. (2010). Women's Economic Participation in Pakistan. Status Report for UNICEF Pakistan. Accessed on September 3 2013, http://eprints.hec.gov.pk/442/1/151.html.htm

Field, A. (2005). "Factor Analysis using SPSS". Retrieved from www.statisticsshell. com/docs/factor.pdf

Freud, A. (1936). Ego \& the Mechanisms of Defense. In The Pelican Freud Library (1977).

Freud, S. (1896). Heredity and the etiology of the neuroses. In Standard edition 3, 142156.

Gerkovich, P. (2004). Women and Men in U.S. Corporate Leadership: Same Workplace Different Realities?, 14, New York, Catalyst.

Güleryüz, G., Güney, S., Aydin, E.M., \& Aşan, O. (2008). The mediating effect of job satisfaction between emotional intelligence and organizational commitment of nurses: a questionnaire survey. Int J Nurs Stud, 45(11), 1625-35.[online] Available from:

http://www.termpapergenie.com/women_3rdworld.html [Acce ssed 15 Feburary2011].

Gunnestad, A. (2006). Resilience in a Cross-Cultural Perspective: How resilience is generated in different cultures. Journal of Intercultural Communication, 11. Retrieved on Sep 252013 from http://www.immi.se/intercultural/nr11/ gunnestad. htm

Maslow, A., (1954). Motivation and personality. New York, NY: Harper. p. 236.

Mostafa, M. (2005). Attitudes towards women managers in the United Arab Emirates: The effects of patriarchy, age, and sex differences, Journal of Managerial Psychology, 20(6), $522-540$.

Ossai, M.C. (2011). Perspectives on working women: Bureau of Labour Satistic. Mediterranean Journal of Social Sciences, 2, 23-28.

Rogers, C. (1947). Some observations on the organization of personality. American Psychologist, 2, 358-368.

Rosenberg, M. (1965) self-esteem Scale. In. Ahmed, R., Sami, S., Khanum, S.J. (2014). Validation of Pakistani version of Reynold's Adolescent Depression Scale-second edition. Pakistan Journal of Clinical Psychology, 13(1), 15-27 
Journal of Social Sciences (COES\&RJ-JSS), 4(4), pp. 934-944

Shireen, J. \& Zeba, S. (2011). Women's Autonomy in India and Pakistan: the influence of Religion and Region, Population and Development Review, 27(4), 687-712.

Wood, R., \& Bandura, A. (1989). Social cognitive theory of organizational management. Academy of Management Review, 14, 361-384.

World Health Organization (2006). Women's Mental Health: A Public Health Concern. Retrieved July 4, 2013, from, http://www.searo.who.int/EN/Section1243/ Section 1310 /Section1343/Section1344/Section1353 5282.htm

Zeab, F. (2011). Feeling of security-insecurity in working-women \& non-working-women in Pakistan, Post Graduate Unpublished thesis. Bucks New University (BNU), UK.

Zehra, S. (2002). Women in Pakistan - Victims of the social and economic desecration. [online] Available from: http://www.marxist.com/Asia/women_in_pakistan. html [Accessed 22 December 2013]. 